\title{
The 'Real Art School': the Cultural Roots of Authenticity in Art Schools in UK and China
}

\section{Yanyan Liao}

Shanghai International College of Fashion and Innovation, Donghua University, Shanghai, China

Room 103, Yifu Building, Donghua University, 1882 West Yan'an Road, Changning

District, Shanghai City, 200051, China. Email: yanyan.liao@live.com, +86 15811180330

Yanyan Liao is an associate professor at the Shanghai International College of Fashion and Innovation, Donghua University. She has been awarded her PhD degree at the School of Art and Design, Nottingham Trent University in the UK, doing research on British and Chinese art schools' culture and identity. She got her MA at Tsinghua University in Beijing and BA at Xi' an Academy of Art. Her research interests are in Western art and design history, art school studies and the area of art and design higher education.

\section{Tom Fisher}

School of Art and Design, Nottingham Trent University, Nottingham, UK

Nottingham Trent University, 50 Shakespeare Street, Nottingham, NG1 4FQ, UK. tom.fisher@ntu.ac.uk, +44 1158488455

Tom Fisher has been Professor in the School of Art and Design at Nottingham Trent University, where he coordinates research, since 2007. He has worked in art schools since 1985. He was awarded his PhD from the department of Sociology at the University of York, and his BA in Fine Art and Art History from the University of Leeds. 


\begin{abstract}
This paper investigates the identity of independent art schools, and art schools in multidisciplinary universities, in the UK and China. Its cross-national research approach uses the concept of collective identity from organizational management theory as a theoretical framework. Drawing on semi-structured interviews with Chinese and British academics, the article addresses the 'image' of art schools - which has both positive and negative aspects. Governments and public opinion takes them to be both the setting for creativity and innovation, and at the same time as being less effective than the other subject disciplines at contributing to economic growth. The article explores this not through an economic argument, but a cultural one. It shows that both independent art colleges and art schools in universities preserve a 'bohemianism' in their organizational identity. It is not novel to note that in the West, this is based in Romanticism, however, it is possible to identify an equivalent, and more ancient, strand in Chinese culture that underlies the identity of 'real art schools' there.
\end{abstract}

\title{
Key Words
}

The real art school, art school identity, bohemian ethic, bourgeois bohemian, NeoTaoist romantic tradition, UK and China

\section{Introduction}

The last thirty years have seen significant changes in art schools' organization, in both the UK and China and the merger of many schools into larger multidisciplinary universities might be expected to have changed how art schools are understood. Outsiders might now see art schools as 'just another university department' and art school teachers, managers and students might think differently about where they work and study. To understand the consequences of changes to the way art and design education is organized requires we understand what art schools mean in Chinese and UK society, which in turn requires that we consider their place in the cultural history of the two countries, and identify what traditions these meanings draw upon. 
This article draws from an interview-based study that used testimony from participants in British and Chinese art institutions ${ }^{1}$ to gauge the effects of merging art schools into universities on their 'character', as defined by people who work in them, 'insiders', and university employees who work in different departments - 'outsiders'. It used two complementary frames of reference. Aspects of identity theory from organizational management helped to understand how outsiders and insiders understand art schools. Other strong themes in the data pointed towards deeply embedded, culturally potent ideas that both these understandings draw upon that are part of the cultural history of both countries.

It was clear from the interview testimony that the concept of a 'real' art school is current in both countries. The analysis of the interview data consequently focused on identifying what makes for 'real-ness' in this sense and it became clear that this denotes a place where certain values and life patterns are prominent, and promoted. The 'real-ness' of art schools, as such, draws on a bohemian ethic, which is present in both Western and Chinese cultural history and underlies the 'real art school' idea in both countries, and in both independent schools, and those merged with larger institutions.

This article compares the Western Romantic ethic of bohemianism and the strand of Chinese neo-Taoist philosophy that we take to be its equivalent, to show two things. First, both independent art schools and art schools in universities can be understood as 'real' art

\footnotetext{
${ }^{1}$ There were thirty participants (14 in the UK and 16 in China) from British and Chinese independent art schools, art colleges in multidisciplinary universities, and non-art and design schools in universities. Four of them were female. The gender imbalance is because the authors concentrated on those in management positions, in which women are statistically less likely to be employed. Nineteen participants (nine in the UK and ten in China) were from art and design schools located inside of universities. Five were from independent art and design institutions (two in the UK and three in China; one UK participant had a background in both a specialist institution and university). Six participants were from non-art and design schools in universities (three in the UK and three in China). The participants' ages ranged was from 35-70. Nineteen of them were Deans, retired Deans, retired Pro Vice Chancellors or Vice Chancellor from art schools, universities, and non-art and design departments in universities. Twenty-five of them have had more than 25 years' experiences in art and design higher education. Some of them had witnessed the art education from the 1960s.
} 
schools, as long as they preserve the deep beliefs and core values of the bohemian ethic. Second, the idea of 'real art school' works both in the UK and China, as both have a bohemian ethic in elements of their cultures, which is the source of the meaning of art schools in both places.

We use "art schools" to indicate Higher Education units that offer art, decorative art and design subjects. The UK interviewees testimony showed that in the UK schools that have both art and design subjects are called "art schools", whether they are independent or merged into universities. Similarly, in China, both insiders and outsiders call schools that have arts and design subjects “Mei Shu Xue Yuan” (美术学院) sometimes shortened to “Mei Yuan” (美院). This literally translates as “academies of fine arts” but the implication is actually “art schools". The Chinese word “Yi Shu” (艺术) literally translates as “art” and is equivalent in usage to "arts" in English, and the literal translation of "Mei Shu": "fine art" has the sense meant by the English usage of "art". Moreover, there is a sense of connection between "art schools" and "Mei Yuan" - they share a sense of nostalgia in art and design people's feelings, to remember and to inherit the characteristics of earlier art-based schools. Based on this small equivalence, "art school" as a short name for art and design institutions both in the UK and China is used in this article.

We first discuss the methodology and theoretical framework the article uses. Second, we introduce the idea of art schools' 'attributed' identity, which refers to how outsiders think about them. This leads to the third section, which discusses the collective identity that art school insiders subscribe to and the concept of 'real art school'. The article then discusses the source of this concept in the 'bohemian' tradition in the UK, and in the corresponding Chinese neo-Taoist ideas, arguing that the interview testimony shows that they underlie the deep beliefs and core values of art schools. Finally, we compare these two traditions to evaluate Western and Chinese Romantic cultures and their influences on art schools' identity.

\section{Methodology and Theoretical Framework}

Semi-structured interviews gave access to the experiences of 30 participants in British and Chinese art and design higher education, whose careers spanned the period of the mergers of art schools and universities, assembled by 'opportunistic or emergent sampling' (Patton 2002, 240). This approach gave access to their 'lived experiences' (Seidman 2006, 9), and a broadly grounded approach to the analysis (Thornberg 2012, 85) gave insights into the 'meanings' 
(Denzin and Lincoln 1994, 361) of these experiences. This made it possible to build the theory of the 'real art school', which emerged from and was grounded in the interview data and is complemented by reference points such as the Romantic ethic that is present in both cultures.

The study was necessarily cross-national, and its comparative framework focused on 'cross-national similarities' and 'cross-national subsets' (Elder 1976, 210) to understand and compare the respective socio-cultural contexts and ethics underlying art schools. Art schools and art and design higher education were examined as 'cross-national subsets', while the UK and China were investigated as 'contexts' rather than in their entirety (Kohn 1987, 714). Consequently, we adopted a 'context dependent, societal approach' (Hantrais 2007, 4). This range of socio-cultural, economic, political, and educational contexts together give access to the similarities and differences in the identity of British and Chinese art schools.

To understand the implications of the aspects of the data that relate to the identity of art schools, we turned to organizational management theory and used Guillaume Soenen and Bertrand Moingeon's theory of the five facets of identity to explore art schools' identity as understood by 'insiders', and in the world at large ${ }^{2}$. They integrate corporate and

2 To investigate the outside perception and the inside reality, hence the collective identity, of art schools, as John Balmer $(2001,248)$ suggested, ideas from the broad area of business identity studies might appear to be relevant, including organizational identity, corporate identity and visual identity. However, visual identity which studies the organization's 'visual (and verbal)' symbols that 'communicate what/who' the organization is (ibid, 254) is not the focus of this article, but would merit further research. In a similar way, although the 'corporate images' which in corporate identity theory refers to the 'perception' of the 'central ideas' by various audiences (Rindova and Schults $1998,48)$ points to the outside perception of art schools, because corporate identity mainly relates to the visual aspect of identity and corporate communication (Balmer 2001, 254) it is not within our scope here. Furthermore, though organizational identity is concerned with beliefs and ideas that are believed and expressed by the organizational members as 'central, enduring, and distinctive' (Whetten $2006,220)$ and therefore is relevant to this article, its complex interrelationship with the study of organizational images in corporate identity (Rindova and Schults 1998, 49) introduces unhelpful definitional and semantic debates (Soenen and Moingeon 2002, 16; Balmer 2001, 254). For these reasons Soenen and Moingeon $(2002,13-34)$ provide a model of collective identity which the paper 
organizational identity and their scheme includes attributed identity, experienced identity, manifested identity (historical identity), professed identity and projected identity (Soenen and Moingeon 2002, 17-28).

Attributed identity is what outsiders believe an organization to be, and includes what its members understand external people think about it. Experienced identity refers to the representation of the shared beliefs about the organization that its members experience - the deepest aspect of an organization's identity that Albert and Whetten define as 'central, enduring and distinctive' to its character (Whetten 2006, 220). Manifested identity can be conceived as the organization's historical identity, its specific, stable, and coherent past character that made it the organization it is today. Professed identity refers to what an organization claims about itself based on its members and management's experiences, beliefs and understandings and becomes part of the projected identity when it is communicated to others through 'communications, behaviours, and symbols' (Soenen and Moingeon 2002, 17 19).

This article uses attributed identity to understand some negative outside perceptions of art schools in the UK and China that we uncovered through contextual research and interview testimony. Experienced identity, manifested identity (historical identity), and professed identity, helped us to explore the beliefs that insiders profess about the 'central, enduring and distinctive' (Whetten 2006, 220) character of art schools. The mediated projected identity can be managed to present the identity of art schools, and this article may contribute to insiders' efforts to do so - presenting their 'real identity'.

\section{The Outsider's Perception: The Art Schools' Attributed Identity}

Art schools are 'at the shop front but never in the engine room'.

This quotation from a female participant who was the Dean and had worked in art schools for more than 25 years refers to an aspect of art schools' attributed identity - what outsiders think about art schools - and demonstrates what art insiders believe outsiders think about

can follow to study respects of both the outside perception and the inside reality, hence the collective identity, of art schools. 
their status. The interviews suggest a perception in both the UK and China that art schools are not central to the purpose of universities - they are 'not important and have mainly decorative purposes' as one interviewee in China put it. Comments from interviewees from non-art and design departments in universities aligned with this impression, suggesting that art schools 'enrich university life', 'provide a culture of beauty'. They are relatively marginalized by the mainstream university culture in both countries. In contrast to this attributed identity, art school insiders emphasized the importance and 'specialness' of art schools, suggesting that outsiders' views are due to the hierarchy between arts subjects and STEM (Science, Technology, Engineering and Mathematics) subjects, and a lack of understanding about art schools and arts subjects.

UK universities fall into two groups. Long established research-focused institutions are distinct from the 'post 1992' universities, created out of polytechnics, reflecting the two traditions that created the UK's higher education system (Pratt 1997, 8-9). Prior to 1992, the universities and colleges of advanced technology in the 'autonomous sector' focused on 'research', 'preservation, extension and dissemination of knowledge for its own sake' (ibid, 9). Alongside this, the focus of 'public sector' technical colleges and colleges of education under the control of local authorities was on vocational, professional and industrial education (ibid, 9). Industrial policy from the late 1960s to the late 1980s saw the majority of the UK's independent art and design schools merged into polytechnics, government actions that to some extent mirrored art schools' attributed identity. From their origin in the mid nineteenth century, art schools had a focus on supporting people's lives, society's needs, and the country's economic development, which matched the purposes of polytechnics, in contrast to the research focus of the older universities.

Similar divisions, based on government rankings, separate Chinese the top-level ' 985 ' universities from the second level '211' universities and the 'third level universities'. China did not amalgamate universities to move art school into second level universities, though most universities in China have established art and design subject disciplines or schools, which they see as attractive to students. This hierarchy in the Chinese educational system, indicates that Chinese society sees art and design subjects as an informal alternative for students who are not good at science and technology and who would not compete with the top-level students in the University Entrance Examinations. The interview with a Chinese participant who was from a senior management position of an art school demonstrated that 
art and design are seen as inferior to science and technology in enhancing national competitive power in technology and innovation. They are seen not as necessary but only as an 'embellishment of life'.

Although government has seen art and design education as a contributor to economic growth in the UK since the middle of $19^{\text {th }}$ century (Bell 1963, 99-101), the perception remains among art school insiders that their subjects are taken to be less able to make that contribution than are STEM subjects. This is reflected in recent UK government policy that emphasizes STEM, excluding arts subjects (Department for Business Innovation \& Skills 2015). However, vigorous assertions of the importance of arts in a cross-disciplinary environment to ensure an innovative future recommend that universities 'promote creativity together with rationalization' and transform STEM into STEAM (with an A for Arts) (Boy 2013, 1; Land 2013, 547).

Even so universities and society at large still show a lack of understanding of arts and design. The interview data suggested that from governments, society, to other departments in the universities, outsiders lack a deep understanding of art schools and arts subjects, influencing art schools' attributed identity. It further suggested that governments in the two countries treat art and design subjects as political and economic tools and student attractors without understanding what they can really contribute and that there are few specialists in government to speak for art and design at a national level.

This lack of understanding at government level and in society means art and design insiders feel misunderstood in their universities. For example, in the UK, as a senior female participant indicated, outsiders may not understand how people can do a degree in a subject such as knitwear, despite its technical complexity. 'People think it is [art and design] not a real subject! We do a BA in knitwear, for example. People think how can you do a degree in knitwear!' In China, this lack of understanding is perhaps more superficial than in the UK and it is certainly more recent, as the modern concepts of 'art', 'craft', and 'design' are relatively newly introduced to the country from Western Europe. To take the example of the Academy of Arts \& Design in Tsinghua, as the first governmental design school in China, several years after it was absorbed into Tsinghua University, people from other schools were still not sure about the art school's exact name. In addition, art and design is not taken to be a serious subject. The function of art and design subjects and the art school is "embellishment". As a Chinese participant from the senior management team of the Academy of Arts \& Design, 
Tsinghua university said, 'the reason that the university needed an art school is superficial. They needed a beautiful campus and the art school can provide the culture of beauty and can enrich university life. It is just like somebody said that "the art school is like an elaborately decorated vase that is only for decoration purposes".'

This marginalization and lack of understanding by governments, society and other university departments risks creating self-doubt in art schools, as well as constructing a negative, and erroneous, attributed identity. To address this situation, it is appropriate to explore the inside reality of art schools as it is important for art people to have confidence in themselves in terms of their identity and values and be ready to present them to outsiders.

\section{The Real Art School Concept: Beliefs and Values}

'A real art school has eccentric teachers and students, and is very alternative and bohemian.'

This quotation is from a male participant with more than thirty years' experience in British art schools and is among three explicit references the interviewees made to the bohemian concept. It also shows the existence of the concept of the 'real art school', which indicates art-school people's beliefs, values and understandings about art schools, expressed as feelings that are significant for their collective identity (Soenen and Moingeon 2002, 17). It shows their beliefs and values about the organization - the experienced, manifested, and professed identity of art schools.

While the appearance of an art school does not determine these feelings about them, it is one of the signs of a 'real art school', part of both its intentionally and its unwittingly projected identity. Outsiders will recognize an art school when they see it by both its deliberate presentation, its marketing, and the sensual experience it presents. Alongside deliberate communications, such as the art schools' logo and buildings its identity is presented through the temporary art on the walls, its relative disorder, the smell of paint and the appearance of staff of students - their clothes and behaviours. One participant described the typical appearance of a 'real art school' in the UK as 'messy', with a 'variety of things going on', and 'smelling of turpentine'. As she explained, '[in a real art school], people made lots of things and it was messy and it did not matter. There was a huge variety of things going on $[\ldots]$ you can see lots of work in process, not finished things [...] you walk in, it smells like turpentine, and there are paintings all over the place. Students are always working [...] 
That nostalgia is about something rather more joyful and free, than "managed" and prestigious and looking good. It's hard to explain.'

Two Chinese participants also noted that 'real art school' qualities are evident in the comportment, dress and behaviour that define the coterie of art students. They have long hair; they wear bizarre and fancy, loose and dirty clothes, which are coloured by oil paints and charcoal pencils; they draw nude models, talk strangely, and behave rebelliously and unconventionally, perhaps dressing up and behaving like this deliberately to convey a message to others "I am a "real artist". As we will show, these features draw on the bohemian traditions present in both UK and Chinese culture.

More important to the 'realness' of the art school than the appearance of the students is its atmosphere. Two British participants suggested that a 'real' art school feels full of humorous, playful and experimental ideas and materials. As one of them indicated, 'the most important is that feeling, atmosphere [...], there was much more sense of humour in a way that people relate to each other [...], [it is] playful about ideas and to play with materials in order to produce new things.' 'The atmosphere is very "avant-garde", very bohemian' the other participant said. They associated this sense of 'avant-garde' and 'bohemian' freedom especially with the period before art schools merged into polytechnics/universities in the UK and China $^{3}$, but it persists in both independent art schools and art schools merged with universities. The interviews suggested that these descriptions of a real art school may be coloured by the participants' nostalgic cultural memory but this does not invalidate them because the characteristics they describe still feature in art schools' manifested identity, and clearly relate to the interviewees' direct experiences.

While this humorous, playful and freewheeling bohemian atmosphere exists in both independent art colleges and art departments in universities, there was evidence that the independent art institutions in the UK and China retain a more distinctly bohemian ethic while the merged art schools in universities combine this with a bourgeois work ethic developed for a capitalist world (McCloskey 2010), that promotes pecuniary virtues such as the prudence to buy low and sell high $(2010,485)$, 'to calculate the consequences, to pursue

\footnotetext{
3 1920s-1960s in the UK, 1920s-1980s in China
} 
the good with competence...the temperance to save and accumulate...to educate oneself in business and life' (2010, 507). These two different ethics, bohemian and bourgeois, are discussed in detail below, and they show themselves in differences between the student degree shows in the two types of art schools.

A UK participant with 30 years experience working in art schools suggested that while degree shows in independent art institutions might look less professional, appearing 'not so resolved', and 'quite rough', this work is 'often much more exciting and radical' aligning to a 'bohemian feeling'. The same participant suggested that degree shows in multidisciplinary universities are characterized by a professional appearance, being 'polished' and 'very well presented'. The fine art work is 'often very cool or like the work of professional artists', and 'ready to go into the wall of contemporary art galleries' and the design work is 'very focused towards industry'. These features indicate the bourgeoisbohemian orientation to business and the art market of this type of art and design college.

As they merged with universities, art schools in the two countries were inevitably influenced by the mainstream culture of the university, which is characterized by a bourgeois rather than bohemian ethic and which imposes certain disciplines on the art school, encouraging it to be less rough-edged and more professional, creating an invisible reference system that is absorbed by art school people and may bring with it a certain restriction. Nonetheless, it is not appropriate to say that an independent art institution is a 'real art school' because it has an obvious art school atmosphere and character and an art school in the university is not 'real' because its bohemian ethic is buried in a bourgeois university culture they are both authentic art schools but with different manifestations of the bohemian factors that characterize their identity. This relationship between bourgeois and bohemian factors is unpicked in the next section.

\section{The Romantic Ethic of Bohemianism underlying British and Chinese Art Schools}

Colin Campbell identifies Bohemianism as a particularly modern phenomenon, a 'social embodiment of Romanticism' $(2005,195)$ that emerged in the early nineteenth century in France, in the aftermath of the Revolution, later spreading to all the major cities in Europe and North America. Wei dates the arrival of this Western Romanticism in China to the 1920s $(2008,139)$ as a consequence of modernization and globalization. For Campbell, it represents the modern tendency to value pleasure above utility and he defines it as 'an unconventional 
and irregular way of life, voluntarily chosen, and frequently involving artistic pursuits' (2005, 195). He identifies Romantics as 'in revolt against what they see as a utilitarian and philistine society, and who find mutual support against its "corrupting" influence in coterie behaviour' (ibid, 195).

The original 'bohemians' were the Gypsies whose place of origin was 'erroneously identified' as the province of Bohemia (Seigel 1999, 5). In the 1830s and 1840s, some young French artists adopted their unconventional and freewheeling lifestyle, living out a bohemian mythology. These French bohemians, impoverished artists with an 'unhappy and neglected genius' (Campbell 2005, 196) saw modern bourgeois society characterized by 'ugliness [and] spiritual emptiness [...] creative poverty and a cowardice of imagination' (ibid, 197). They created their intellectual circles in cafes or restaurants where they could meet, talk, flirt, argue, or even brawl (ibid, 196). They lived in the corners of large cities that asked the lowest rents and though living in poverty, they had a high taste in art, using artistic ways to express themselves and maintaining a commitment to pleasure, which Campbell notes is an intangible feeling. Like the sense of being in a 'real art school' pleasure is an aesthetic phenomenon. These unconventional and irregular ways of artistic life are the embodiment of Romanticism and bohemianism and recur throughout subsequent history, developing into a commercialized concept of lifestyle which has had a close connection with fashion and interior decoration, such as the Beat Generation of the 1950s, the hippie movement of the 1960s, and the boho chic style in the early 21 st century. Alongside this commercialization, the Romantic ethic legitimized modern art and design higher education, working its way into the deep beliefs and core values of art schools.

As its Romantic origins have played out in the bohemian character of modern art schools, the bohemian art ethic has blended with a bourgeois work ethic. Consequently, people in art schools have become what David Brooks defines as the 'bohemian bourgeois' (bobos) $(2010,79)$, Richard Lloyd describes as the 'neo-bohemians' $(2010,12)$, and Richard Florida identifies as the core of 'creative class' $(2014,908)$. Bohemian and bourgeois can be seen as a pair of intimate opposites, as Jerrold Seigel indicates, "they imply, require, and attract each other' $(1999,5)$. When they emerged in the $19^{\text {th }}$ century, it was easy to distinguish bohemians from the bourgeois. The bourgeois are conformists, traditionalists, middle-class moralists, while the bohemians, nearly always sons and daughters of wealthy, middle class parents, are the countercultural and artistic 'free spirits', such as the 'hippies and 
the Beats', who 'flouted convention' (Brooks 2010, 66-70). However, since the end of the 20th century, the line between bohemian and bourgeois has blurred into a new upper class (Brooks 2010, 66-70).

This new bohemian/ bourgeois class are 'highly educated folk who have one foot in the bohemian world of creativity and another foot in the bourgeois realm of ambition and worldly success' (Brooks 2010, 79), though, this does not mean they have abandoned the bohemian ethic. They are the 'neo-bohemians', 'affluent professionals' rather than 'starving artists' (Lloyd 2010, 1196), 'creative, edgy and rich' at all once (ibid, 1178). Typical representatives of this new class are the affluent art and design 'professionals' who combine the bourgeois work ethic with the hedonistic and artistic bohemian ethic. As Fuente indicated (2010, 552), their art education is the prelude to this hybrid of work and play, and the breeding ground for their mixing of bohemianism and entrepreneurialism.

Simon Frith and Howard Horne suggest 'the art school experience is about commitment to a working practice, to a mode of learning which assumes the status of lifestyle...Art is everything. Art is life' (1987, 28-29). With their serious/ playful bohemian lifestyle art schools legitimate the modern configuration of art and design education, an example of romanticism and bohemianism advocating self-expression and self-realization and introducing 'intrinsic hedonism into areas such as education and art' (Campbell, 2005, 201). They also provide a philosophy of recreation and an ethical support for consumption, production and a taste for novelty. Art and design education serves as training grounds for the combination of art, pleasure, novelty, modern fashion patterns, original products, commerce and consumption, at the same time building supporting and legitimising the art school ethos. This ethic works for both independent and merged schools. Both contain bohemian factors and bourgeois factors that are represented by the mainstream university culture, and very often, the university culture not only influences their own art schools, but also spreads beyond them to have an impact on independent art schools.

\section{The Neo-Taoist Romantic Tradition as an Analogue for the Romantic Ethic of Bohemianism}

The modern pattern of art schools in China was an outcome of Modernization and an East/ West cultural collision, so it was influenced by the Romantic ethic spreading into China from the West in the 1920 s to underpin the contemporary 'feeling' of the 'real art school'. But this 
Western ethic of bohemianism established itself alongside China's own analogue of romanticism: Taoism, which is equivalent to Western cultural modernization post 1700, but occurred far earlier, in the Weijin Southern and Northern Dynasties (220-589 CE). NeoTaoism involved a revolt against feudal and Confucian rules through artistic activities that could realize an individual's value, through the pursuit of pleasure, as modernism in the West developed out of Romanticism's revolt against Classical ideals and the bourgeois social order and values. These two threads work alongside Western Romanticism to legitimize the 'real art school' ethic in contemporary China.

Developing from a collision between Confucian and Taoist ideas, the Neo-Taoist Romantic tradition influenced the spirit of Chinese art and the philosophy and system of Chinese painting in the Weijin Southern and Northern Dynasties (220-589 CE) (Feng 1948, 217), a period that saw disordered politics and a miserable society along with tremendous freedom, wisdom and enthusiasm in people's spiritual and aesthetic aspects (Zong 1987, 126141). The equivalent of bohemians in the Neo-Taoist Romantic tradition are the 'Seven Sages of the Bamboo Grove'. These distinguished artists, ideologists, musicians, literati and calligraphers, adopted Neo-Taoist philosophy in revolt against the ugliness and spiritual emptiness of reality through artistic activities such as painting, playing music and chess during the period of the Weijin Dynasties. The Seven Sages came from aristocratic families who abandoned their political and economic privileges, withdrawing from society to live in austere solitude, seeking freedom, self-realization and peace by rejecting the ruling class, despising feudal and Confucian ethics and rules and abandoning the cruel social system. Some rejected the social system in their hearts, adopting a contemptuous manner but were not openly against society. Others behaved unconventionally in their daily life by, for instance leaving their hair dishevelled, going about naked or without shoes or drinking to excess, their revolt against restrictive feudal hierarchies marked by dress and behaviour.

They gathered for convivial philosophical conversations, 'Qing Tan' (清谈), which Feng interprets as the 'best (most Taoistic) thoughts in the best language and tersest phraseology', which could only happen between 'comparable' friends at a 'high intellectual level' in a certain bamboo grove. When involved in these 'most refined intellectual activities' (Feng 1948, 231), the Seven Sages drank, versified, talked about their political ambitions. Their significance for Chinese Romantic culture was that they brought legendary Taoist philosopher Zhuangzi to their conversations, who expanded Laozi's thoughts and strongly 
influenced Neo-Taoism. His philosophy influenced their unconventional and uninhibited life style, and resulted in the sentimental and emotional features of Neo-Taoism.

The appreciation of inner beauty within humanity and nature by the Seven Sages is another 'Romantic' factor in Weijin Culture and Neo-Taoist philosophy. The elegant and free Weijin style and manner meant they used unconventional dress and behaviour to resist feudal/Confucian ethics, but also appreciated elegance as a reflection of 'beautiful minds'. This Romantic aspect of Neo-Taoism is distinct from the bohemian rejection of the comforts of life, including expensive and decent clothes, but resembles Aestheticism in the West, combining Romanticism and Dandyism. The Seven Sages emphasized appearance as they believed that an elegant and decent appearance reflected a beautiful mind and thoughts. They had the idea of eliminating the importance of the body but thought highly of people's inner thoughts and the beauty of personality and individuality. More comparisons between Western and Chinese romantic ethics are made in the next section.

\section{Comparison between Bohemians in Western Romantic Culture and the Seven}

\section{Sages of the Bamboo Grove in the Chinese Romantic Tradition}

This discussion of the Western and Chinese romantic traditions shows there are similarities and differences between the bohemians and the Seven Sages of the Bamboo Grove, in terms of their status and background, the norms they rejected, their behaviours, their artistic activities, appearance and lifestyle. Their attitudes to nature also reflect equivalent elements in the philosophies of the West and East.

The most obvious difference between British and Chinese romantic cultures is that they arose in different time periods and different places and reflect different social systems. However, while the systems were different, they share the fact that they grew up in response to the restrictions they faced. Bohemians, who to some extent had proletarian characteristics, were restrained by the bourgeois social system that they rejected, while the Seven Sages of the Bamboo Grove were discontented with the feudal social system but they were not able to overthrow it. Though the restrictions were different, in both cases these groups were reacting to, and accommodating with, their social environment.

Second, their manners of rejecting societal norms were different. The Neo-Taoist revolt against society was less extreme than that of the Bohemians, who rejected what they saw as a utilitarian and philistine culture in a relatively extreme manner to pursue their 
individual self-expression and self-realisation. The Seven Sages by contrast, adopted a relatively introversive and moderate stance against their social setting and set out to realize the individual's value through a combination of two threads of their philosophies. This combination of a Taoist and Neo-Taoist Romantic ethic provided them with critical awareness and self-expression, and helped them resist convention, though the strong influence of Confucianism remained in their thinking, providing the doctrine of the Mean or the way of Moderation - they did not overdo their actions. The degree of eclecticism that came to characterize Chinese cultural tradition means these two threads are still relevant in modern Chinese society at large, as well as in art institutions.

While bohemian Romanticism avowed a sense of heroic conduct as a pioneering example to society, the Seven Sages of the Bamboo Grove, resembled the Aesthetic tradition in the West in their escape from the ugliness of the world but did not seek to change that world, beyond influencing Chinese art and painting. These contrasting extroversive and introversive manners can also be read out of their gathering places. The Bohemians preferred to meet and talk in urban public places such as cafes and restaurants while the Seven Sages had their pure conversations where they would not be disturbed.

Despite these differences, there are many similarities between the Romantic traditions in the UK and China, like their attitudes to nature. The tradition that the Seven Sages represent conforms to natural and cosmic rules. In Eastern Taoist philosophy, nature is something to protect human beings and something to live with, played out in the fact that the Seven Sages met where they did, in a Bamboo Grove, seeking protection from it. Although it is not an especially prominent feature of bohemianism, Romanticism more broadly has a strong relation to ideas of nature and to being 'in' nature. This is in contrast to the prevalent European tendency towards mastery over nature (Kluckhohn and Strodtbeck 1961; Alfred 2009, 100), though Western Romantic culture values the appreciation of nature (Harrison, no date), as do eastern cultures (Alfred 2009, 100).

While both the bohemians and the Seven Sages were from wealthy and high status backgrounds, the bohemians came from bourgeois capital owning families, while the aristocratic families of the Seven Sages of the Bamboo Grove were always related to political status, as well as wealth. In both cases, this social/ political context meant rejecting what they saw as the spiritual emptiness and ugliness of society by behaving unconventionally, so in a sense were both restricted as well as motivated by what they rejected. This somewhat 
paradoxical combination of critical awareness and rebellious spirit underlying bohemianism and the Seven Sages of the Bamboo Grove, is precisely the spirit that legitimizes the ethos of art and design institutions in the modern UK and China.

A 'real' art school in the UK embodies bohemian/romantic characteristics, the extroversive romantic ethic behind rebellious activities such as the Hornsey student protests in the 1960s in the UK. However, after merging into polytechnics from the end of 1960s to the 1980s, the bohemian art ethos was more overtly combined with a bourgeois work ethic, re-balancing the culture in art schools around a neo-bohemian ethic, combining creativity and self-realization with entrepreneurialism. A 'real art school' in China is also a hybrid - of the bohemian spirit, Western modernism and China's own neo-Taoist romantic tradition. The influence of Confucianism, means that extreme activities such as the Hornsey student protests are hard to imagine, however, in modern Chinese art schools, the two threads of Chinese traditional philosophy and the western modern romanticism exist together and do cause collisions and 'sparks'. The critical awareness and rebellious nature of the romantic ethic are inherited and carried forward by Chinese art schools which means it is valid to call them 'real' art schools. The bohemian ethic and neo-Taoist spirit as 'central, enduring, and distinctive' (Whetten 2006, 220) characters in art schools both in the UK and China are not only deeply embedded in the history of art schools as part of their manifested identity, they are also part of their experienced identity and professed identity. This makes art schools what they are in the present and is likely to influence what their members wish them to become in the future.

\section{Conclusion}

This article has compared the identity of British and Chinese art schools through the two versions of the romantic ethic that draw from the corresponding bohemian and neo-Taoist traditions, and which legitimize belief in the intangible value and authenticity of a 'real art school'. Outsiders tend not to understand art schools and perceive them at a superficial level, seeing them as inferior to science and engineering departments. To stop this lack of understanding diminishing art school education, it is useful for art and design insiders to reflect on the authenticity of art schools - that intangible feeling and core value that concretises and actualizes the concept of the 'real art school'. The 'atmosphere' that art 
school insiders experience influences what they profess about themselves and their role in the world.

Independent art institutions and art schools in universities seem to share this atmosphere, preserving the art school's deep beliefs and core values, though with different features in terms of resources and structure. The merger of independent art schools and universities does, to some extent, change art schools, influencing their culture and helping them to be multidisciplinary. However, the art-school mentality, the unconscious, taken-forgranted values and beliefs that can be traced through Western and Eastern cultural histories cannot be easily changed.

It is not enough for art school insiders to understand the 'realness' of art schools. Art schools must project an identity that emphasizes all the contributions they can make, particularly their ability to link culture, science, technology, manufacturing and consumerism. Their multidisciplinary environment makes this linkage possible - they not only contain art, craft, and design subjects but also have cross-disciplinary potentials, relating the needs of 'high culture' via aesthetic experience, to craft and manufacturing industries.

As most art schools are now in universities, they combine a bohemian Romantic ethic with a bourgeois work ethic, and symmetrically, art schools have brought the bohemian/ romantic spirit into contact with the mainstream values represented by the wider university culture. The iconoclastic romantic ethic is a powerful source of cultural creativity, which makes art schools a propellant for innovation. In a mainstream culture that values science and engineering, art schools as a connector carry the weight of art, craft, and design, and link science, manufacturing and consumerism.

\section{References}

Alfred, M.V. 2009. Diversity Culture and Human Performance in Work Organizations. In: V.C.X. Wang, and K.P. King, eds., Fundamentals of Human Performance and Training. IAP, 2009, pp. 89-110.

Balmer, J.M.T. 2001. Corporate identity, corporate branding and corporate marketing: Seeing through the fog. European Journal of Marketing, 35(3/4), pp. 248-291.

Bell, Q. 1963. The Schools of Design. London: Routledge and Kegan Paul. 
Boy, G.A. 2013. August. From STEM to STEAM: toward a human-centred education, creativity \& learning thinking. In Proceedings of the 31st European Conference on Cognitive Ergonomics (p. 3). ACM.

Brooks, D. 2010. Bobos in Paradise: The New Upper Class and How They Got There. Kindle Edition. New York, London, Toronto, Sydney: Simon \& Schuster Paperbacks.

Campbell, C. 2005. The romantic ethic and the spirit of modern consumerism. London: Blackwell Publishers.

Denzin, N.K. and Lincoln, Y.S., eds. 1994. Handbook of Qualitative Research. Los Angeles, London, New Delhi, Singapore, Washington DC: SAGE Publications.

Department for Business Innovation \& Skills. 2015. Policy paper 2010 to 2015 government policy: public understanding of science and engineering(online). Government Digital Service. Available at:https://www.gov.uk/government/publications/2010-to-2015government-policy-public-understanding-of-science-and-engineering/2010-to-2015government-policy-public-understanding-of-science-and-engineering\#appendix-3-inspiringstudents-to-study-science-technology-engineering-and-mathematics (Accessed 11/19 2016).

Elder, J.W. 1976. Comparative cross-national methodology. Annual Review of Sociology, 2, 209-230.

Feng, Y. 1948. A Short History of Chinese Philosophy. London: Collier Macmillan Publishers.

Florida, R. 2014. The Rise of the Creative Class, Revisited. Kindle ed. Basic Books.

Frith, S. and Horne, H. 1987. Art into Pop. Routledge.

Fuente, E.d. 2010. Beyond the Academic 'Iron Cage': Education and the Spirit of Aesthetic Capitalism. In: D. Araya, and M.A. Peters [eds] Education in the Creative Economy: Knowledge and Learning in the Age of Innovation. New York, Washington DC/Baltimore, Bern, Frankfurt, Berlin, Brussels, Vienna, Oxford: Peter Lang, pp. 552-553.

Hantrais, L. 2007. Contextualization in cross-national comparative research. In: L. Hantrais, and S. Mangen [eds] Cross-national Research Methodology \& Practice. London and New York: Routledge, 2007, pp. 3-18. 
Harrison, G. no date. Romanticism, Nature, Ecology (online). Available at: http://www.rc.umd.edu/pedagogies/commons/ecology/harrison/harrison.html (Accessed $11 / 192016)$.

Kohn, M.L. 1987. Cross-national research as an analytic strategy: American Sociological Association, 1987 Presidential address. American Sociological Review, 52 (6), 713-731.

Land, M.H. 2013. Full STEAM ahead: The benefits of integrating the arts into STEM. Procedia Computer Science, 20, pp.547-552.

Lloyd, R. 2010. Neo-Bohemia: Art and Commerce in the Postindustrial City. Second Edition edn. New York and London: Routledge.

Lloyd, R. 2010. Neo-Bohemia: Art and Commerce in the Postindustrial City. Kindle Edition edn. New York and London: Routledge.

McCloskey, D.N. 2010. The Bourgeois Virtues: Ethics for an Age of Commerce. University of Chicago Press.

Patton, M.Q. 2002. Qualitative Research \& Evaluation Methods. SAGE Publications.

Pratt, J., 1997. The Polytechnic Experiment: 1965-1992. Buckingham: The Society for Research into Higher Education \& Open University Press.

Rindova, V.P., and Schultz, M., 1998. Identity within and Identity without: Lessons from Corporate and Organizational Identity. In: D.A. Whetten, and P.C. Godfrey, eds., Identity in Organizations: Building Theory through Conversations. London: SAGE Publications, 1998, pp. 46-55.

Seidman, I. 2006. Interviewing as qualitative research: A Guide for Researchers in Education and the Social Sciences. 3rd ed. New York and London: Teachers College, Columbia University.

Seigel, J. 1999. Bohemian Paris: Culture, Politics, and the Boundaries of Bourgeois Life, 1830-1930. Illustrated edn. Baltimore and London: Johns Hopkins University Press.

Soenen, G. and Moingeon, B. 2002. The five facets of collective identities: Integrating corporate and organizational identity. In: B. Moingeon and G. Soenen [eds] Corporate and Organizational Identities: Integrating strategy, marketing, communication and organizational perspectives. London: Routledge, pp. 13-34. 
Thornberg, R. 2012. 11 Grounded theory. In: J. Arthur, M. Waring, R. Coe and L. Hedges [eds] Research Methods and Methodologies in Education. Los Angeles, California, London: SAGE Publications.

Wei, H. 2008. An Overview of Bohemianism. Hunan University Journal, 13 (1), 139-142.

Whetten, D.A. 2006. Albert and Whetten revisited: Strengthening the concept of organizational identity. Journal of Management Inquiry, 15(3), pp.219-234.

Zong, B. 1987. Essays and Criticism (Shi Shuo Xin Yu) and Aesthetics in Jin Dynasty. In: Artistic Conception. $1^{\text {st }}$ ed. Beijing: Beijing University Press, pp. 126-141. 